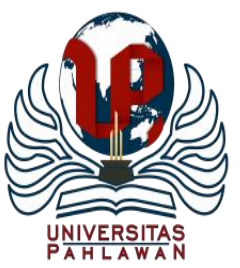

Jurnal Basicedu Volume 4 Nomor 3 Tahun 2020 Halm. 725-732

JURNAL BASICEDU

Research \& Learning in Elementary Education

https://jbasic.org/index.php/basicedu/index

\title{
Gender and Self-regulated Learning During COVID-19 Pandemic in Indonesia
}

\author{
Tommy Tanu Wijaya ${ }^{1}$, Zhou Ying ${ }^{2}$, Lin $\mathrm{Suan}^{3}$ \\ Guangxi Normal University, Guilin, China ${ }^{1,2,3}$ \\ Email: tommytanu@ foxmail.com ${ }^{1}$
}

\begin{abstract}
Abstrak
Coronavirus jenis baru yang ditemukan menyebabkan penyakit COVID-19. COVID-19 adalah penyakit menular yang disebabkan oleh jenis coronavirus yang baru ditemukan. Ini merupakan virus baru dan penyakit yang sebelumnya tidak dikenal sebelum terjadi wabah di Wuhan, Tiongkok, bulan Desember 2019. Pandemi COVID 19 membuat kegiatan belajar mengajar berhenti untuk sementara waktu. Kegiatan belajar dilakukan siswa secara mandiri dirumah masing-masing. Penelitian ini bertujuan untuk membandingkan self-regulated learning antara siswa laki-laki dan siswa perempuan pada masa pandemik COVID-19 di Indonesia. Penelitian ini menggunakan metode kuantitatif dengan metode kuisioner. Populasi pada penelitian ini adalah siswa sekolah dasar di Indonesia. Kuisioner self-regulated learning dibagikan secara online. Hasil dari penelitian ini menunjukkan adanya efek hawgent dynamic mathematics software terhadap self-regulated learning pada pandemi COVID-19. Hasil penelitian menunjukkan bahwa self-regulated learning siswa perempuan lebih baik dibandingkan siswa laki-laki pada pandemi COVID-19.

Kata kunci : pandemi COVID-19, gender, self-regulated learning
\end{abstract}

\begin{abstract}
A new coronavirus has been found to cause the outbreak of the COVID-19 pandemic. COVID-19 is an infectious disease caused by a newly discovered coronavirus. This is a new virus and a disease. It has not been discovered before the outbreak in Wuhan, China, in December 2019. The COVID-19 pandemic stopped teaching activities for a while. Students conduct learning activities independently in their homes. The purpose of this study was to compare the self-regulated learning of male and female students during the COVID-19 epidemic in Indonesian. This research uses quantitative and survey methods, and the research object is primary school students in Indonesia. The self-regulated learning questionnaire has been shared online. The results of this study show that hawgent dynamic mathematics software has an impact on the self-regulated learning of the covid-19 pandemic. In the co-population 19 pandemic, self-regulating female students are better than male students in learning.
\end{abstract}

Keywords: Covid-19 Pandemic, Gender, Self-regulated learning

Copyright (c) 2020 Tommy Tanu Wijaya, Zhou Ying, Lin Suan

Corresponding author :

Address : Yucai Road 15, Guilin, Guangxi, China

Email : tommytanu@foxmail.com

ISSN 2580-3735 (Media Cetak)

Phone : +6287825204424

ISSN 2580-1147 (Media Online)

DOI: $10.31004 /$ basicedu.v4i3.422 


\section{INTRODUCTION}

Coronavirus are a group of virus that can cause disease in animals or humans. Several types of coronavirus are known to cause respiratory infections in humans, ranging from cold coughs to more severe coughs, such as Middle East Respiratory Syndrome (MERS) and Severe Acute Respiratory Syndrome (SARS) (Murphy, 2020). A new coronavirus has been found to cause COVID19. COVID-19 is an infectious disease caused by newly discovered coronavirus. This is a new virus and a previously unknown disease before it broke out in Wuhan, China, in December 2019. Pandemic coronavirus began to become the main focus in the spring of 2020. By the end of January, the new coronavirus disease (COVID-19) infected 294,000 people in more than 187 countries in 2019 (Peters et al., 2020). During this pandemic, many countries closed cities to prevent the spread of the virus. All activities are temporarily suspended and the community is isolated at home (Zhu \& Liu, 2020).

The corona virus pandemic (COVID-19) is believed to have an impact on the quality of education (Favale, Soro, Trevisan, Drago, \& Mellia, 2020; Hall, 2020). During this pandemic, the government conducted social distractions and blockades in cities across China. Teaching and learning activities were forced to stop, and all students from Elementary School to University stopped teaching and learning activities for a period of time (Peters et al., 2020). Distance education is currently being implemented, which is a problem for teachers and students. The distance learning method adopted during the COVID-19 pandemic resulted in neither teachers nor students being the best choice in the learning process (Daniel, 2020). This aims to prevent the spread of coronaviruses from becoming more dangerous. Therefore, during this pandemic, students use many technology-based applications at home to learn (Hall, 2020; Watson, McKinnon, Prior, Richards, \& Green, 2020).

When students study at home, it is undeniable that there are many factors that interfere with students' serious study. Students may be too lazy to study by themselves and always want to play or watch TV. When students encounter difficult problems, they are too lazy to try to solve the problem by themselves. Therefore, it can be said that the family learning environment does not really allow students to study seriously. Coupled with the lack of attention from parents and teachers.

In China, technology-based learning media that can be rapidly developed can be used for teaching (Cunhua, Ying, Qunzhuang, \& Wijaya, 2019; Wijaya, Ying, \& Suan, 2020; Yi, Ying, \& Wijaya, 2019). Many technology-based applications are available, and students can continue to learn even if they do not go to school temporarily. Some methods used for learning activities during the pandemic include video learning, online courses, etc.

Hawgent dynamic math software is math software from Guangzhou, China (Figure 1). Hawgent has a dynamic design and is easy to use (Wijaya, Ying, \& Purnama, 2020a). Hawgent dynamic math software is designed according to the needs of novice teachers and is used to teach math materials in schools. Therefore, when the 
teacher uses this application, the teacher has no difficulty in producing teaching materials. Teachers can use hawgent software to explain various mathematical problems, such as calculus, algebra, probability, etc (Cunhua et al., 2019; Wijaya, Ying, \& Purnama, 2020b). Based on the completed research, dynamic mathematics software has been successfully developed to teach fractions, trigonometry, and has been shown to improve student learning outcomes (Wijaya, Sukma, Purnama, \& Tanuwijaya, 2020).

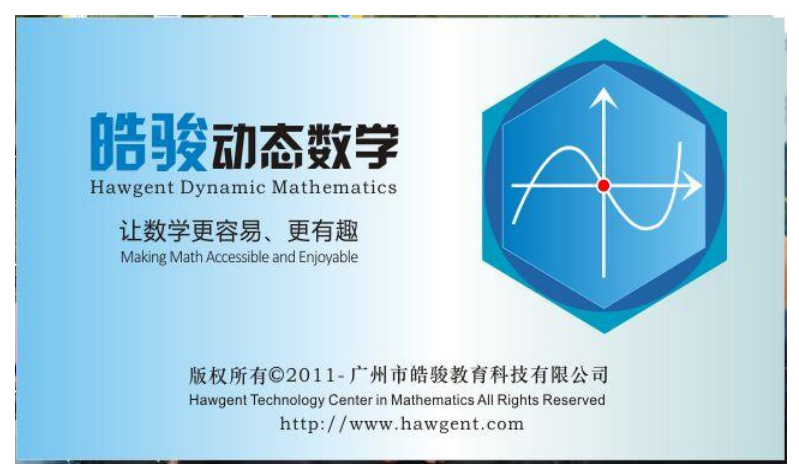

Figure 1. Hawgent Dynamic Mathematics Software

During the pandemic, hawgent dynamic math software was used as a medium for distance learning. The students from Guangxi Normal University in China, directed by Tang Jianlan, produced 5-10 minutes of interactive learning videos to discuss mathematical problems. This is because according to existing research, the effective video learning duration is 5-10 minutes (Daniel, 2020). The color display and excellent animations make learning videos very interesting, and are equipped with background music, which can attract students 'attention and enable them to study more seriously. It is hoped that even if students do not go to school, the teaching media using powerful dynamic math software can improve the common autonomy in the 19th century pandemic.

Self-regulated learning is the process of students' active learning (Darr \& Fisher, 2004). Self-regulated learning is defined as the independent process of taking proactive actions without the help of others, setting learning goals, determining learning manpower and material resources, selecting and implementing appropriate learning strategies, and evaluating learning outcomes (Wongsri, N., Cantwell, R. H., \& Archer, 2002). Students' self-regulated learning ability to learn independently can improve students' learning quality. Factors that affect student learning are: emotions, motivation, thoughts, and beliefs. Some research has been carried out, and it turns out that learning can improve students' learning outcomes and mathematical ability. Based on the above explanations, the self-regulated learning indicators used in this study include: learning initiative; determining the purpose of learning; learning control; treating difficulties as challenges; selecting and determining the correct learning strategy; evaluating the learning process and results.

Based on the above background, the purpose of this study is to investigate the differences in the influence of hawgent dynamic math software on co-learning among male and female undergraduates in Indonesia under the age of 19.

\section{METHOD}

The method in this study is descriptive and qualitative. The study describes the impact of powerful dynamic math software on learning and 
learning in the COVID-19 male and female student pandemic. The respondents to this study were 107 students from Indonesia, including 66 male students and 51 female students.

The tools in this study are the student's questioner using online questioner. Table 1 is lists the questioners of the students '"questioners" and "self-regulated learning".

Tabel 1. Questioner Self-regulated Learning

\begin{tabular}{|c|c|c|c|c|c|}
\hline \multirow[t]{2}{*}{ No } & \multirow[t]{2}{*}{ Question } & \multicolumn{4}{|c|}{ Answer } \\
\hline & & $\begin{array}{l}\text { Very } \\
\text { agree }\end{array}$ & Agree & $\begin{array}{c}\text { Not } \\
\text { agree }\end{array}$ & $\begin{array}{c}\text { Very not } \\
\text { agree }\end{array}$ \\
\hline 1 & $\begin{array}{l}\text { During the } \\
\text { pandemic, my } \\
\text { goal is to } \\
\text { learn using } \\
\text { video learning } \\
\text { every day }\end{array}$ & & & & \\
\hline 2 & $\begin{array}{l}\text { I have my } \\
\text { own learning } \\
\text { strategy }\end{array}$ & & & & \\
\hline 3 & $\begin{array}{l}\text { During the } \\
\text { pandemic, I } \\
\text { have to study } \\
\text { for several } \\
\text { hours every } \\
\text { day }\end{array}$ & & & & \\
\hline 4 & $\begin{array}{l}\text { I am lazy to } \\
\text { study alone at } \\
\text { home }\end{array}$ & & & & \\
\hline 5 & $\begin{array}{l}\text { I can do my } \\
\text { homework }\end{array}$ & & & & \\
\hline 6 & $\begin{array}{l}\text { Even if I don't } \\
\text { go to school, I } \\
\text { always study } \\
\text { at home }\end{array}$ & & & & \\
\hline 7 & $\begin{array}{l}\text { I always feel } \\
\text { so hard when } \\
\text { doing my } \\
\text { homework }\end{array}$ & & & & \\
\hline 8 & $\begin{array}{l}\text { I am ready to } \\
\text { study } \\
\text { tomorrow }\end{array}$ & & & & \\
\hline 9 & $\begin{array}{l}\text { I am very lazy } \\
\text { using learning } \\
\text { videos using } \\
\text { hawgent } \\
\text { dynamic } \\
\text { mathematics } \\
\text { software }\end{array}$ & & & & \\
\hline 10 & $\begin{array}{l}\text { If I still don't } \\
\text { understand, I } \\
\text { usually watch } \\
\text { the learning }\end{array}$ & & & & \\
\hline
\end{tabular}

\begin{tabular}{|c|c|}
\hline & video again \\
\hline 11 & $\begin{array}{l}\text { The COVID- } \\
19 \text { pandemic } \\
\text { did not stop } \\
\text { me from } \\
\text { studying even } \\
\text { at home }\end{array}$ \\
\hline 12 & $\begin{array}{l}\text { I summarized } \\
\text { the topic from } \\
\text { the video }\end{array}$ \\
\hline 13 & $\begin{array}{l}\text { I only watch } \\
\text { videos to } \\
\text { learn because } \\
\text { the pictures } \\
\text { are interesting }\end{array}$ \\
\hline 14 & $\begin{array}{l}\text { Although } \\
\text { studying at } \\
\text { home during } \\
\text { the pandemic } \\
\text { is very } \\
\text { difficult, I still } \\
\text { try to continue } \\
\text { studying }\end{array}$ \\
\hline 15 & $\begin{array}{l}\text { I only watch } \\
\text { videos to } \\
\text { learn because } \\
\text { of my parents }\end{array}$ \\
\hline 16 & $\begin{array}{l}\text { If the teacher } \\
\text { doesn't ask, I } \\
\text { won't watch } \\
\text { that video } \\
\text { learning }\end{array}$ \\
\hline 17 & $\begin{array}{l}\text { I used the } \\
\text { learning } \\
\text { method as } \\
\text { expected to } \\
\text { study at home }\end{array}$ \\
\hline
\end{tabular}

Use Microsoft Excel and SPSS 25 to process the results of the instruments that have been distributed to students to understand the impact of hawgent dynamic math software on self-regulated learning in the COVID-19 male and female student pandemic.

\section{RESULTS AND DISCUSSION}

Table 2. Description of Self-regulated Learning by Male and Female Students

\begin{tabular}{lcc}
\hline & Male students & $\begin{array}{c}\text { Female } \\
\text { students }\end{array}$ \\
\hline Mean & 42.34 & 45.39 \\
Std. deviation & 2.42 & 5.83 \\
N. Min & 40.00 & 28.00 \\
N. Max & 47.00 & 53.00 \\
\hline
\end{tabular}


According to the data that can be seen in table 2, we can see that score for the male students and female students are 42.34 and 45.39 respectively. This means that the initial selfregulated learning of the female students in coronavirus pandemic is higher than male students. From the data above, we can also see that the standard deviation of the male students and female students are 2.42 and 5.84 respectively. Which means that the self-regulated learning male students is more evenly distributed than in the experimental class. To see more clearly the difference in the students' self-regulated learning, the data is then processed using SPSS 25 to know if there is a significant different or not.

Table 3. Independent sample testing

\begin{tabular}{lccc}
\hline & $\begin{array}{c}\text { sig (2- } \\
\text { tailed) }\end{array}$ & $\begin{array}{c}\text { Mean } \\
\text { Difference }\end{array}$ & $\begin{array}{c}\text { Std. } \\
\text { Error } \\
\text { Differen } \\
\text { ce }\end{array}$ \\
\hline $\begin{array}{l}\text { Assumed } \\
\text { equal } \\
\text { variance }\end{array}$ & .002 & -3.05248 & .96034 \\
$\begin{array}{l}\text { Does not } \\
\text { assume } \\
\text { equal } \\
\text { variance }\end{array}$ & .000 & -3.05248 & \\
\hline
\end{tabular}

In table 3 , we can see that self-regulated learning has a significant value. Use sig's value to get the average difference between boys and boys on $t$ test. $0.002<0.05$, so it can be concluded that the students's self-regulated learning for female students is better than male students.

\section{Discussion}

Hawgent dynamic mathematics software has attractive design and innovative design. Learning videos are very easy for students to understand.
According to the requirements of the 2013 course, the video is produced at various stages, and various elementary mathematics concepts are explained through problem-based learning concepts. The video learning hawgent dynamic math software lasts 5-10 minutes. Table 2 lists the stages of stupid learning videos using problembased learning methods.

Table 4. Video Stages of Hawgent Dynamic Mathematics Software Learning

\begin{tabular}{|c|c|c|}
\hline No & Steps & Information \\
\hline 1 & $\begin{array}{l}\text { Student adaptation } \\
\text { to problems }\end{array}$ & $\begin{array}{l}\begin{array}{l}\text { Hawgent } \\
\text { mathematics }\end{array} \\
\begin{array}{l}\text { dynamic } \\
\text { learning voftware } \\
\text { issues related to daily } \\
\text { activities }\end{array}\end{array}$ \\
\hline 2 & Organize students & $\begin{array}{l}\text { Memorable learning videos } \\
\text { can guide students to find } \\
\text { mathematics } \\
\text { information }\end{array}$ \\
\hline 3 & $\begin{array}{l}\text { Guide individual } \\
\text { deep thinking }\end{array}$ & $\begin{array}{l}\text { Hawgent learning video } \\
\text { guides students to solve } \\
\text { existing problems }\end{array}$ \\
\hline 4 & $\begin{array}{l}\text { Commence to } \\
\text { practice }\end{array}$ & $\begin{array}{l}\text { Hawgent } \\
\text { mathematics } \\
\text { learning video can help } \\
\text { students try their own practice }\end{array}$ \\
\hline 5 & $\begin{array}{l}\text { Analyze and } \\
\text { evaluate the } \\
\text { problem-solving } \\
\text { process }\end{array}$ & $\begin{array}{l}\text { In the final stage, } \\
\text { reinforcement learning videos } \\
\text { can help students take a } \\
\text { conclusions }\end{array}$ \\
\hline
\end{tabular}

By using a problem-based learning method, students can easily understand the materials provided. This is consistent with the research that has been conducted, and problem-based learning methods can improve students 'learning outcomes and make it easier for students to obtain materials provided by teachers. Therefore, the researchers integrated problem-based learning methods into the video, hoping that students can more easily understand the problems in daily life. 


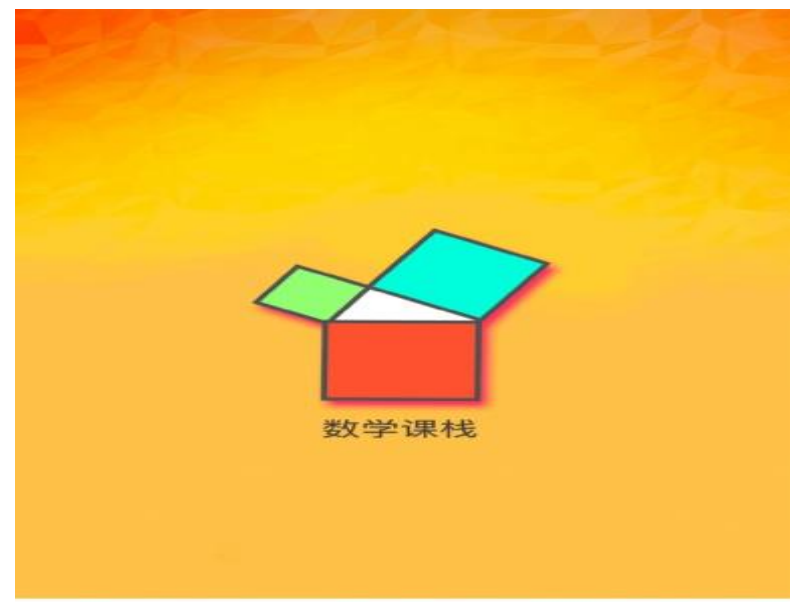

一个能玩的数学APP

Figure 2. The Application of Hawgent Dynamic Mathematics Software Learning Media on WeChat Applications

You can access hawgent learning videos through WeChat. College students and Professor Tang Jianlan of Guangxi Normal University always update the new materials of Elementary School, Junior High School and High School every day. The learning video application logo on the WeChat application is shown in figure 2. Xiao Fang (figure 3) is a virtual teacher using dynamic math software. The method of teaching this method is both interesting and interesting, so that students can easily understand the content in the video.

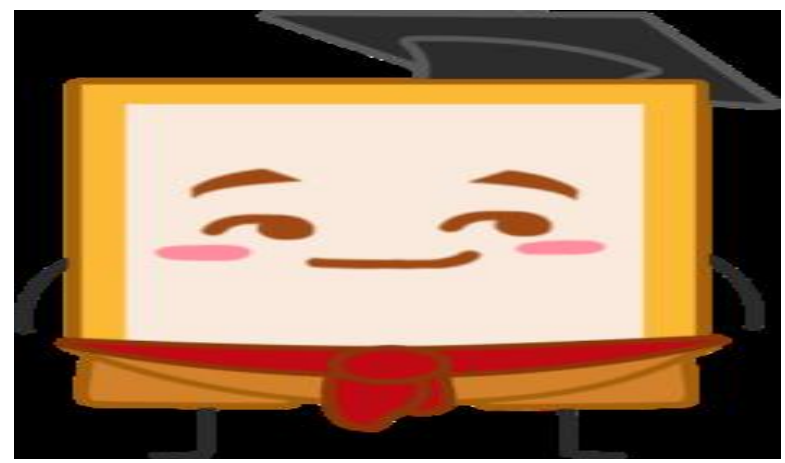

Figure 3. Virtual Teacher in Hawgent Dynamic Mathematics Software
The researchers also interviewed several elementary school students to understand their reaction to dangerous dynamic math learning video learning. The results of the interview are also used as an assessment tool for the next learning video. Table 3 lists the results of students' responses to the learning ability of dynamic math software.

Table 5. Students' Respond and Suggestion for Evaluation

\begin{tabular}{|cl|}
\hline Students & \multicolumn{1}{c|}{ Statement } \\
\hline S1 & $\begin{array}{l}\text { Hawgent dynamic mathematics software } \\
\text { learning video is very interesting }\end{array}$ \\
S2 & $\begin{array}{l}\text { I have been waiting for new learning } \\
\text { videos }\end{array}$ \\
S3 & $\begin{array}{l}\text { Hawgent learning videos can help me } \\
\text { understand the basic concepts of } \\
\text { mathematics }\end{array}$ \\
S4 & $\begin{array}{l}\text { Hawgent learning videos helped me } \\
\text { study at home during the coronavirus } \\
\text { pandemic }\end{array}$ \\
S5 & $\begin{array}{l}\text { If possible, make learning videos more } \\
\text { challenging }\end{array}$ \\
S6 & $\begin{array}{l}\text { Ilike to learn using video learning } \\
\text { mathematics software should be longer }\end{array}$ \\
S7 & $\begin{array}{l}\text { My parents are very happy that I am } \\
\text { learning by myself. }\end{array}$ \\
\hline
\end{tabular}

The children still feel like playing. They will take the opportunity to play rather than learn. Therefore, when this pandemic coronavirus infection, the teacher cannot pay attention to the learning of all students. Compared with learning, male students can use this opportunity to play games. Compared with female students, female students pay more attention to themselves and listen to their parents' orders. In this way, female students studying independently are better than male students.

To overcome this problem, parents can better control their children at home. Therefore, even if they do not use this popular coronavirus to 
go to school, they can learn independently. When parents pay attention to their children, in addition to improving their children's study conscientiousness, they can also promote a good relationship between parents and children. Finally, good learning will improve students' learning outcomes.

\section{CONCLUSION}

Based on the results of the completed studies, the proven dynamic math software has been shown to improve students' regulated learning in the COVID-19 pandemic. An interesting learning video makes it easy for students to understand the materials provided, and also makes them interested in learning other mathematical materials. Based on interviews with elementary school students, hawgent dynamic mathematics software also received a positive response. In further research, people hope that this hawgent dynamic mathematics software learning video can be obtained in multiple languages. Therefore it can be used by other countries.

\section{ACKNOWLEDGEMENT}

We would like to thanks to Guangxi Normal University for the research fund which has been given to the researcher. In 2019, Guangxi Higher Education Undergraduate Teaching Reform Project "research and practice of effective mathematics teaching guided by systematic thinking ability" (Project No.: 2019JGZ110); in 2020, Guangxi Graduate Education Innovation Plan Project "Research on training mode of improving high-level thinking ability" (Project No.: XJGY2020010).

\section{REFERENCES}

Cunhua, L., Ying, Z., Qunzhuang, O., \& Wijaya, T. T. (2019). MATHEMATICS COURSE DESIGN BASED ON SIX QUESTIONS COGNITIVE THEORY USING HAWGENT DYNAMIC MATHEMATIC. Journal On Education, 02(01), 36-44.

Daniel, S. J. (2020). Education and the COVID-19 pandemic. Prospects, (0123456789). https://doi.org/10.1007/s11125-020-09464-3

Darr, C., \& Fisher, J. (2004). Self-regulated learning in Mathematics class. In NZARE Conference, Turning the Kaleidoscope, 2426.

Favale, T., Soro, F., Trevisan, M., Drago, I., \& Mellia, M. (2020). Campus Traffic and eLearning during COVID-19 Pandemic. 176(April).

https://doi.org/10.1016/j.comnet.2020.107290

Hall, R. (2020). Covid-19 and the Hopeless University at the End of the End of History. Postdigital Science and Education. https://doi.org/10.1007/s42438-020-00118-3

Murphy, M. P. A. (2020). COVID-19 and emergency eLearning: Consequences of the securitization of higher education for postpandemic pedagogy. Contemporary Security Policy, $\quad 0(0), \quad 1-14$. https://doi.org/10.1080/13523260.2020.17617 49

Peters, M. A., Wang, H., Ogunniran, M. O., Huang, Y., Green, B., \& Chunga, J. O. (2020). China's Internationalized Higher Education During Covid-19: Collective Student Autoethnography.

Watson, A., McKinnon, T., Prior, S.-D., Richards, L., \& Green, C. A. (2020). COVID-19: time for a bold new strategy for medical education. Medical Education Online, 25(1), 1764741. https://doi.org/10.1080/10872981.2020.17647 41 
Wijaya, T. T., Sukma, M., Purnama, A., \& Tanuwijaya, H. (2020). Pengembangan media pembelajaran berbasis tpack menggunakan hawgent dynamic mathematics software. 03(03), 64-72.

Wijaya, T. T., Ying, Z., \& Purnama, A. (2020a). THE EMPIRICAL RESEARCH OF HAWGENT DYNAMIC MATHEMATICS TECHNOLOGY INTEGRATED INTO TEACHING. Journal Cendekia: Jurnal Pendidikan Matematika, 04(01), 144-150.

Wijaya, T. T., Ying, Z., \& Purnama, A. (2020b). Using Hawgent Dynamic Mathematics Software in Teaching Trigonometry. International Journal of Emerging Technologies in Learning, 15(10), 215-222. https://doi.org/10.3991/ijet.v15i10.13099

Wijaya, T. T., Ying, Z., \& Suan, L. (2020). Using Geogebra in Teaching Plane Vector. Journal of Innovative Mathematics Learning, 3(1), $15-23$.

Wongsri, N., Cantwell, R. H., \& Archer, J. (2002). The validation of measures of self-efficacy, motivation and self-regulated learning among Thai tertiary students. In Annual Conference of the Australian Association for Research in Education.

Yi, L., Ying, Z., \& Wijaya, T. T. (2019). The Trend of Mathematics Teaching Method Has Change From Fragments To Systematics. Journal Cendekia: Jurnal Pendidikan Matematika, 3(2), 471-480. https://doi.org/10.31004/cendekia.v3i2.137

Zhu, X., \& Liu, J. (2020). Education in and After Covid-19: Immediate Responses and LongTerm Visions. Postdigital Science and Education. https://doi.org/10.1007/s42438020-00126-3 